\title{
DEFORMATION IN MULTILAYER FIBERGLASS BEAMS AT DIFFERENT POSITIONS OF CONCENTRATED LOAD
}

\author{
Sanja Junušić \\ Josip Juraj Strossmayer University of Osijek, Faculty of Civil Engineering Osijek, student \\ Tihomir Štefić \\ Josip Juraj Strossmayer University of Osijek, Faculty of Civil Engineering Osijek, MSc. \\ Aleksandar Jurić \\ Josip Juraj Strossmayer University of Osijek, Faculty of Civil Engineering Osijek, Associate Professor
}

\begin{abstract}
We analyzed the load and deformation in hollow beams made from multilayered glass-fiber-reinforced polymer, specifically assessing deformation under concentrated load. We performed nonlinear numerical analysis on beam with rectangular cross-sections with set dimensions and material properties. Beams with three different spans were analyzed, loaded with two concentrated forces at varying distances between applied force and supports. As the force was increased, we assessed the deformation near the supports. These results are shown in dimensionless diagrams, where the ratio of the applied and initial force correlates to the ratio of deformation near the support to deformation near the mid-span.
\end{abstract}

Key words: glass-fiber-reinforced polymer, load, deformation, nonlinear numerical analysis, dimensionless diagram

\section{ANALIZA DEFORMACIJA VIŠESLOJNIH NOSAČA OD STAKLOPLASTIKE, NA RAZLIČITIM MJESTIMA KONCENTRIRANOG UNOSA OPTEREĆENJA}

Sažetak: U radu se analiziraju opterećenja i deformacije kod šupljih nosača od pločaste višeslojne stakloplastike te ukazuje na problem koncentriranih sila. Nelinearna numerička analiza je provedena na nosaču pravokutnog poprečnog presjeka s unaprijed odabranim dimenzijama i karakteristikama materijala. Analizirani su nosači s tri različita raspona, a svaki je opterećivan dvjema koncentriranim silama, gdje je varirana udaljenost sila od oslonaca. Za postepeno povećanje sile praćena je promjena vrijednosti deformacije nad osloncima. Rezultati su prikazani bezdimenzionalnim dijagramima, odnosno, za omjer pripadne sile s početnom silom prati se omjer deformacije nad ležajem i progiba u polovini raspona.

Ključne riječi: stakloplastika, opterećenje, deformacija, nelinearna numerička analiza, bezdimenzionalni dijagram 


\section{Introduction}

Composites are polymers with reinforcing materials added to improve their heat stability, environmental stability, and other mechanical properties. Glass-fiber-reinforced polymers are often combinations of polyester resin and glass fibers [1]. In our previous work [2], a hollow, glass-fiber-reinforced polymer beam was analyzed for whether it could be used to construct different types of ceilings and floors [3]. To more precisely determine the characteristics of the beam composite, tensile specimens were prepared from this composite and put under axial tension [4]. Figure 1 shows the dimensions of the tensile specimen.

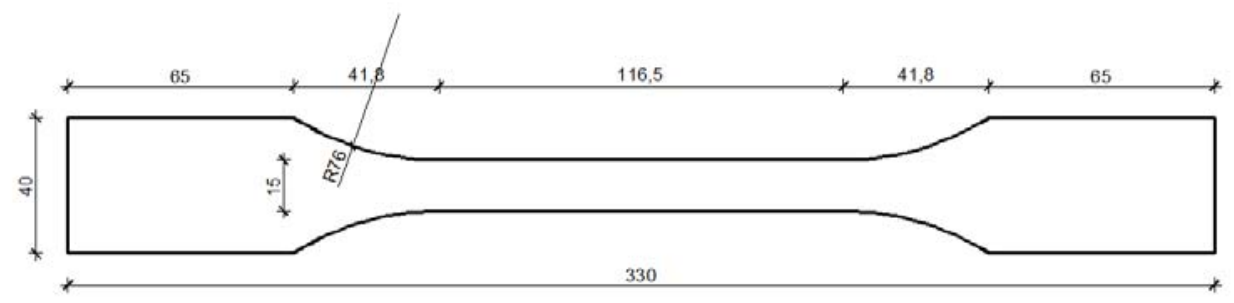

Figure 1. Dimension of the tensile specimen

Figure 2 shows the stress-strain characteristics of the tensile specimen. The fiber-reinforced polymer exhibited homogenous behavior; it acted almost completely elastic with little plastic deformation at high load. When its bearing capacity was exceeded, it failed in brittle fracture [3].

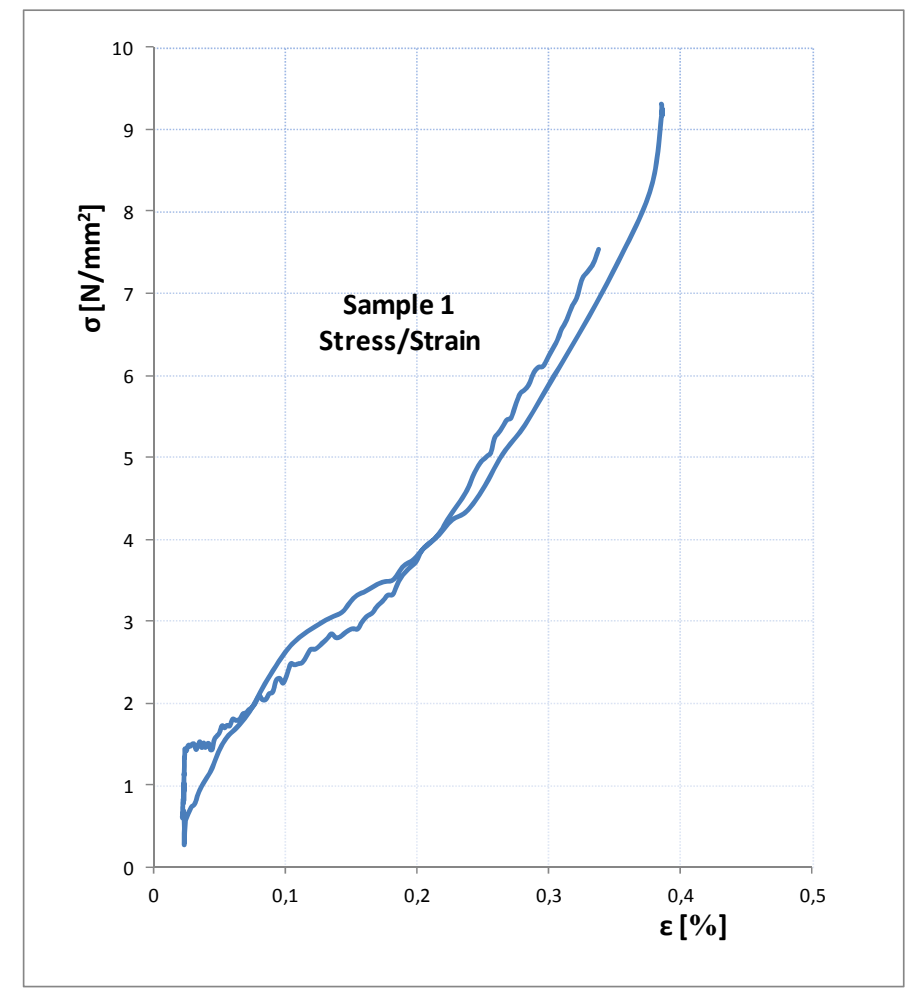

Figure 2. Stress-strain behavior of the tensile specimen 
Also, in our previous work [2], the glass-fiber-reinforced polymer beams were tested using four-point bending (4PB), as shown in Fig. 3.

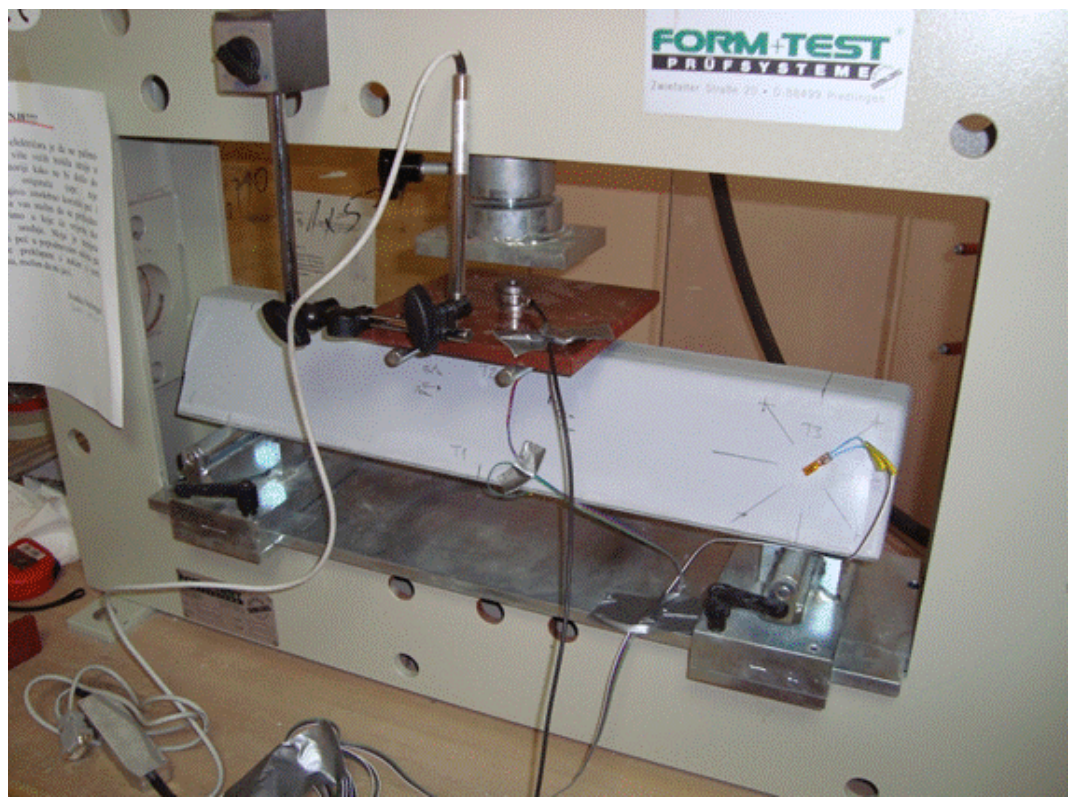

Figure 3. Test rig for fiber-reinforced polymer beams

While analyzing the behavior of these beams, we found that significant stress concentration near the applied concentrated forces caused deformation of the beam, as shown in Fig. 4. Deformation occured both at the site of applied load and at the supports. These result show that this combination of loading and supports is unfavorable for this material, cross-section, and beam.

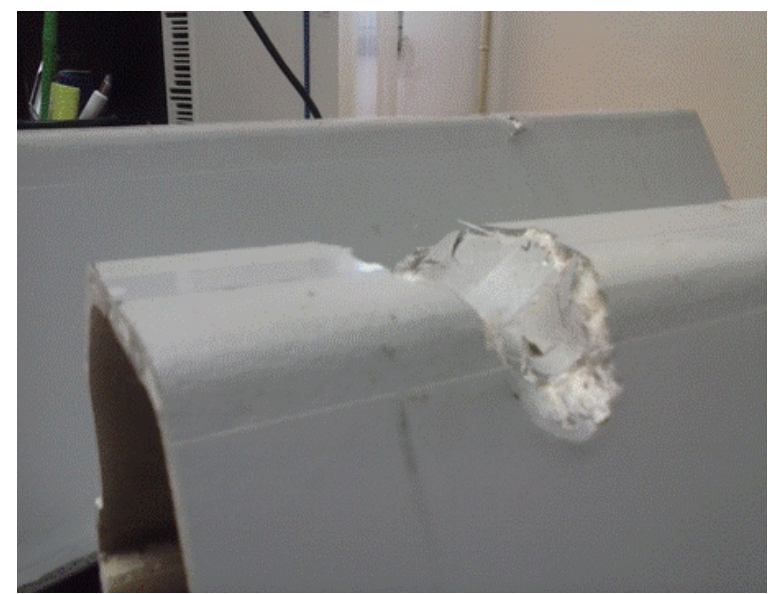

Figure 4. Photograph of beam deformation

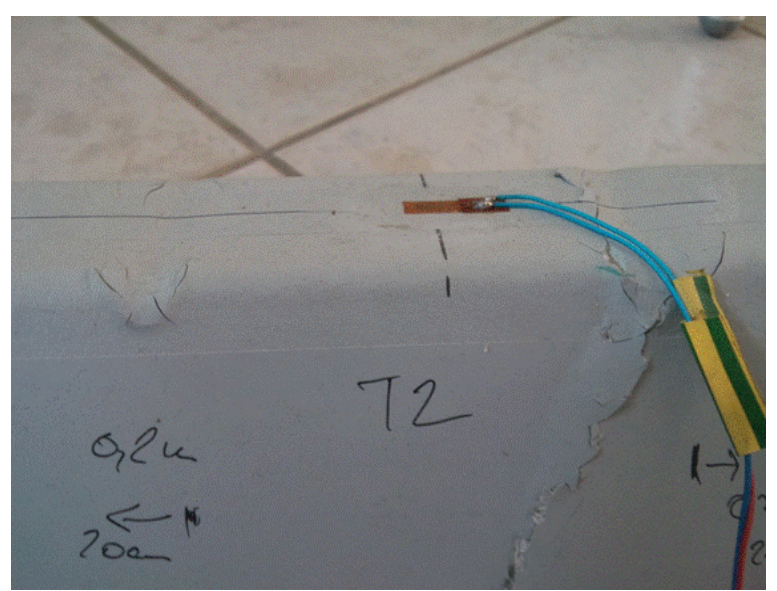

Figure 5. Photograph of beam failure

This deformation contributed much to the failure of the beam, as shown in Fig. 5. Glass-fiber-reinforced polymers are brittle, but the onset of failure can still be recognized. In these materials, failure occurs by gradual failure of the fibers, by separation of the fibers and matrix, or both. In the present paper, we analyze the contribution of vertical deformation near the supports to failure and how it correlates to the vertical mid-span deformation. This analysis can also be conducted at the load site by causing vertical deformation in that area. 


\section{Nonlinear numerical analysis}

We analyzed beams with $50 \mathrm{~cm}$ spans with hollow rectangular cross-sections, comparing them with beams of 50 $\mathrm{cm}$ spans with trapezoidal cross-sections from our previous work [2]. We further analyzed these beams by using a nonlinear numerical model [5] from a software package [6]. To make these results comparable, we chose the geometries of the beams to be as close as possible to those of the trapezoidal beams. The moment of inertia was $I_{y}=2434 \cdot 10^{6} \mathrm{~mm}^{4}$. The material properties and input geometries of the beams were taken from [2]. The material properties are as follows: $E=7000 \mathrm{MPa}, v=0.3, G=400 \mathrm{MPa}, f_{d}=60 \mathrm{MPa}$. Figures 6 and 7 show the results for the trapezoidal and rectangular cross-sections, respectively. In these figures, the $x$-axis is the length/span direction used to calculate the deformation ratio of the beam, and the $y$-axis is the direction of applied force.

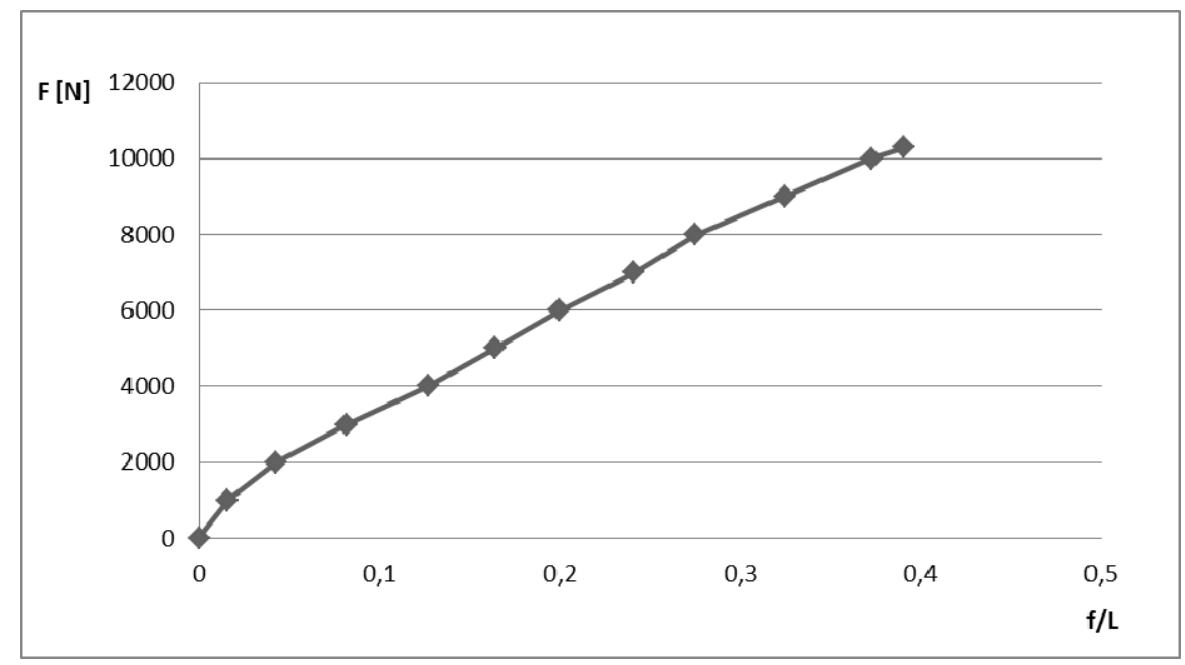

Figure 6. Deformation of span and length, trapezoidal beam cross-section [2]

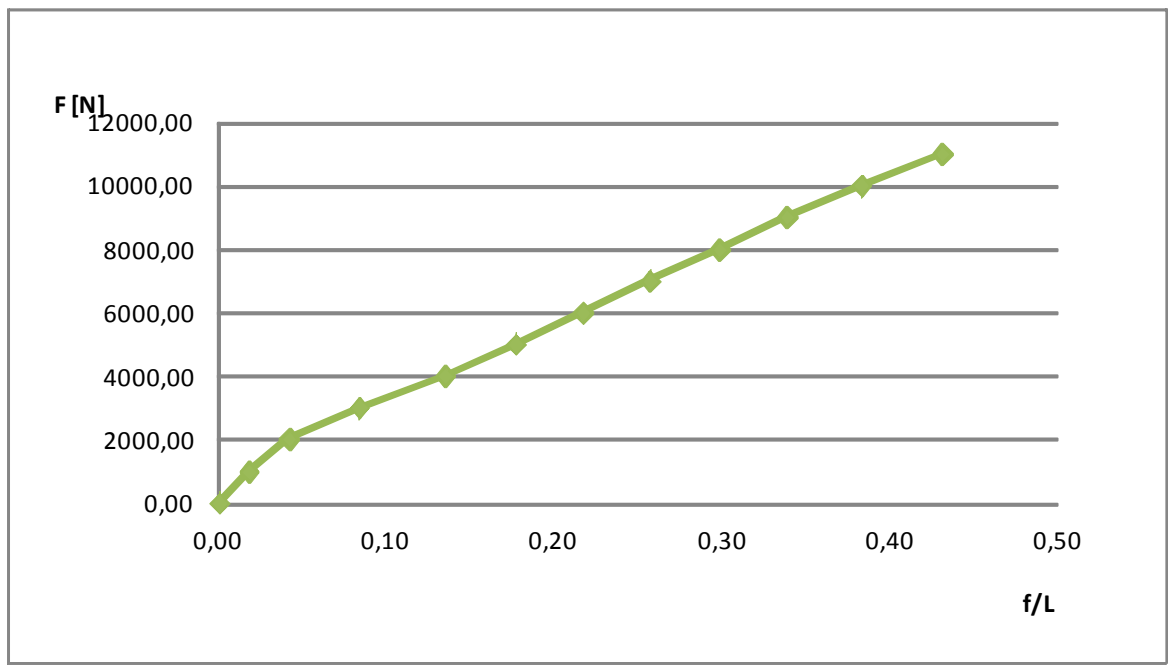

Figure 7. Deformation of span and length, rectangular beam cross-section

After selecting a cross-section and material properties, we analyzed beams with different spans. The beams were loaded with two concentrated forces, varying the distance between forces and supports along the span. For each beam, we varied the distance between the force and supports as $6 \%, 11 \%$, and $17 \%$ of the span. The static model was a beam supported at two ends, as shown in Fig. 8 . We analyzed three spans: $L=90,140$, and 240 $\mathrm{cm}$. The chosen rectangular cross-section was $100 \mathrm{~mm}$ tall, $60 \mathrm{~mm}$ wide, and its walls were $9 \mathrm{~mm}$ thick. 


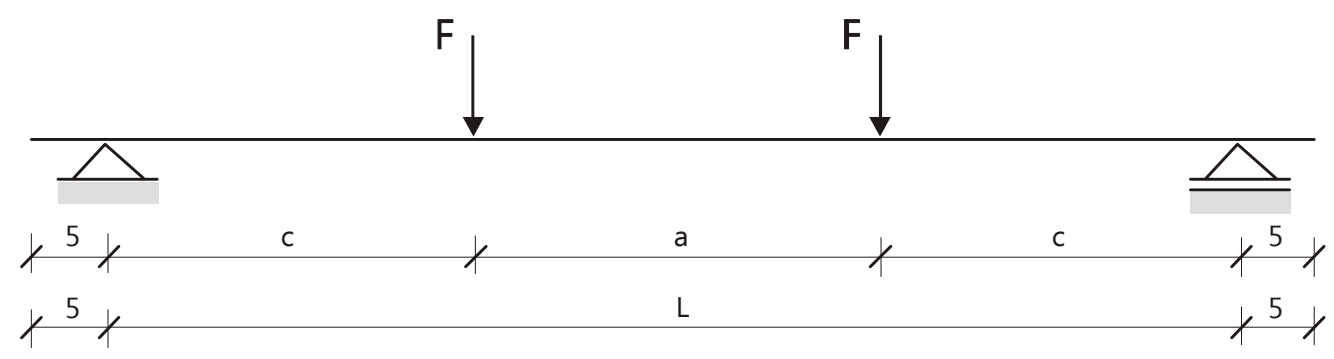

Figure 8. Static model of the beam

While testing the beams, we found vertical deformation above the support, so we made the finite element mesh in that area denser to produce more accurate results. Figure 9 shows an example of the stress concentration near a support.

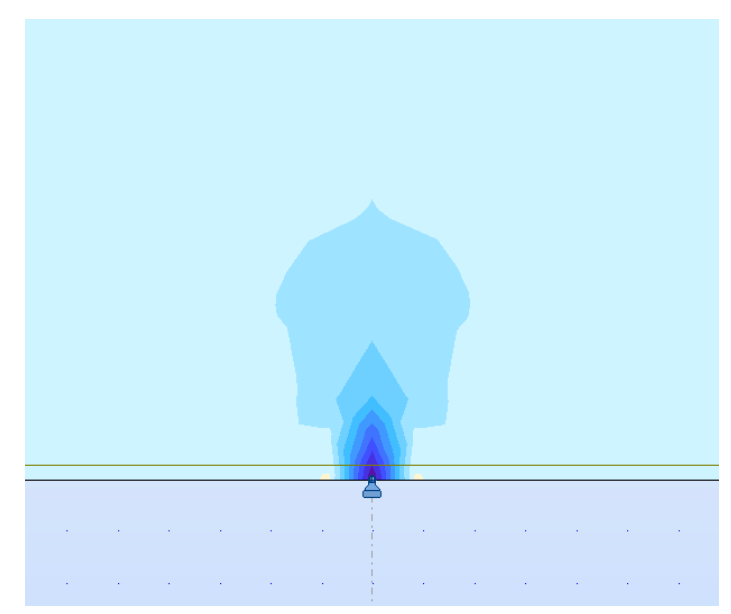

Figure 9. Stress concentration near a support

\section{Analysis Results}

Our results are shown in dimensionless diagrams, where the $x$-axis is the $y / f$ ratio and the $y$-axis is the $F / F_{p}$ ratio. The $F / F_{p}$ ratio is the ratio of force applied to the beam during the test and the initial force, and the $y / f$ ratio is the ratio of support deformation to mid-span deformation. Figures 10,11, and 12 show the results for beams with spans of $90 \mathrm{~cm}$, with the force applied $6 \%, 11 \%$, and $17 \%$ of the beam span away from the support, respectively. 


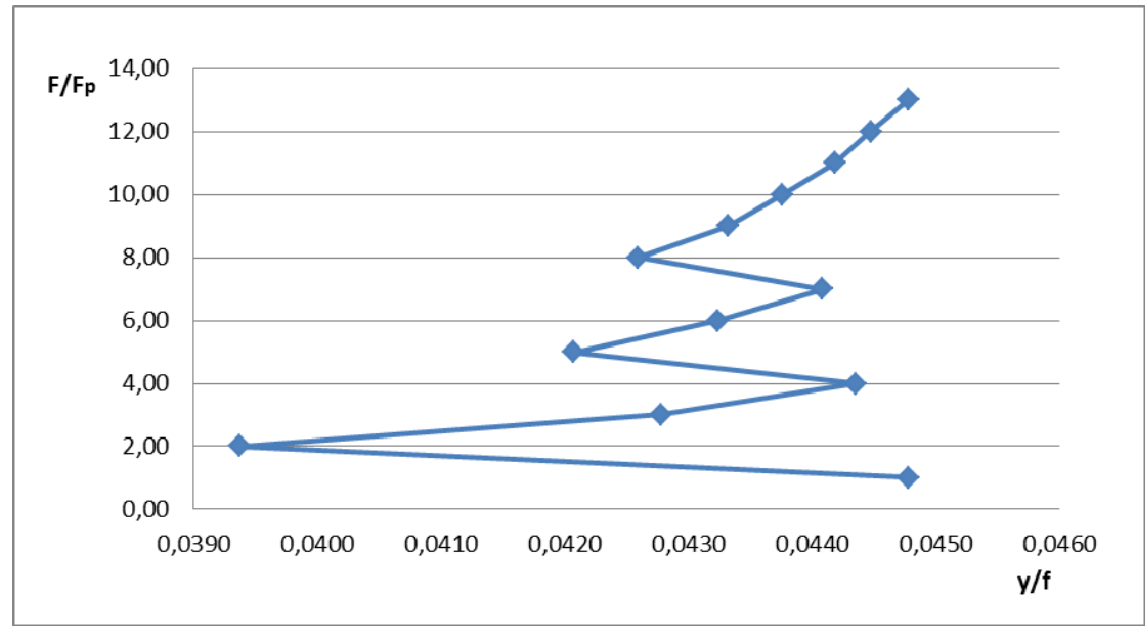

Figure 10. Mechanical testing; beam span of $90 \mathrm{~cm}, 6 \%$ of span

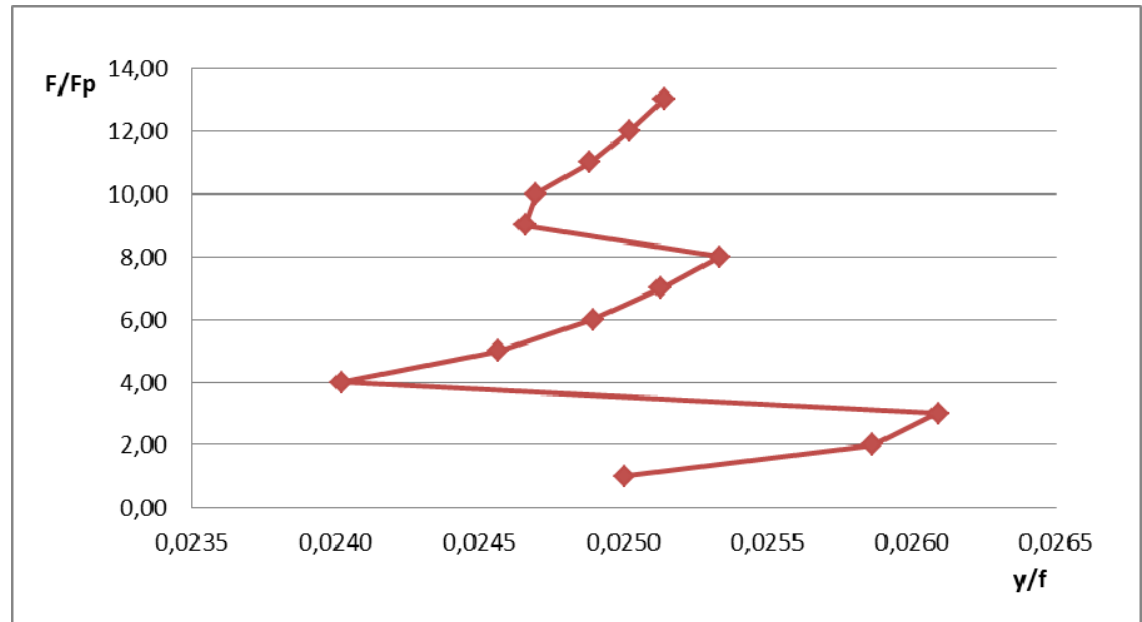

Figure 11. Mechanical testing; beam span of $90 \mathrm{~cm}, 11 \%$ of span

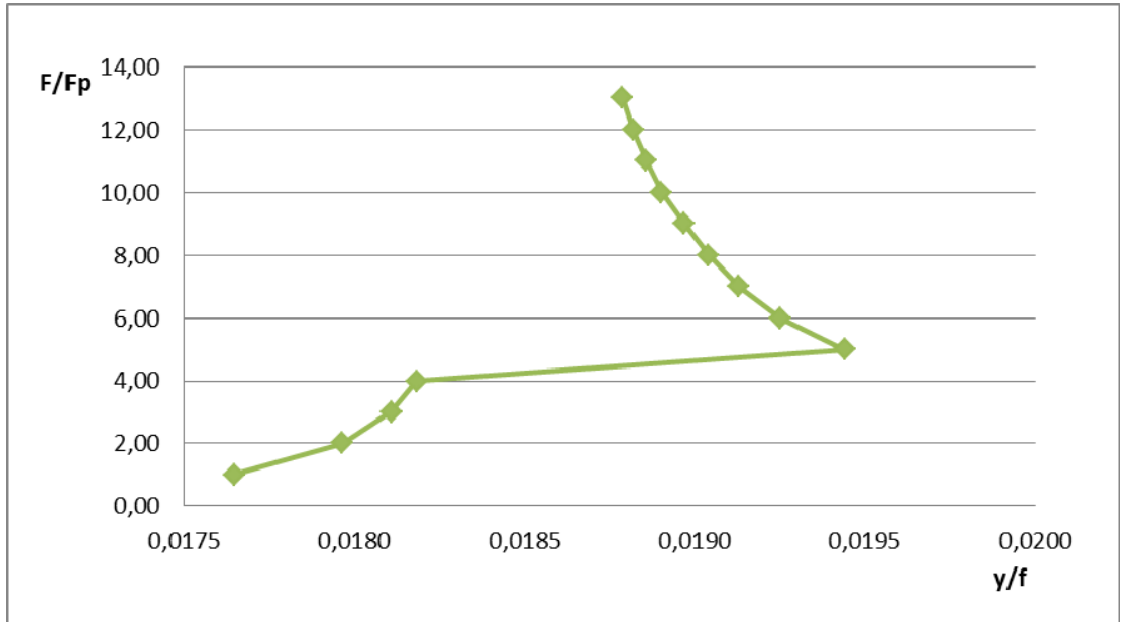

Figure 12. Mechanical testing; beam span of $90 \mathrm{~cm}, 17 \%$ of span 
Figures 13,14 , and 15 show corresponding diagrams for beams with spans of $140 \mathrm{~cm}$.

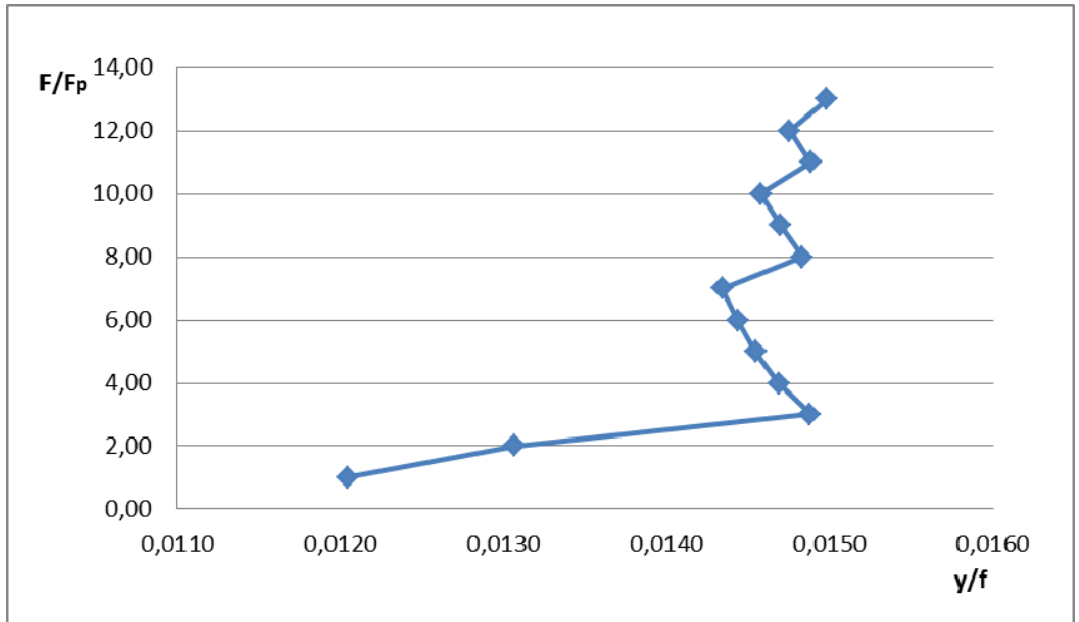

Figure 13. Mechanical testing; beam span of $140 \mathrm{~cm}, 6 \%$ of span

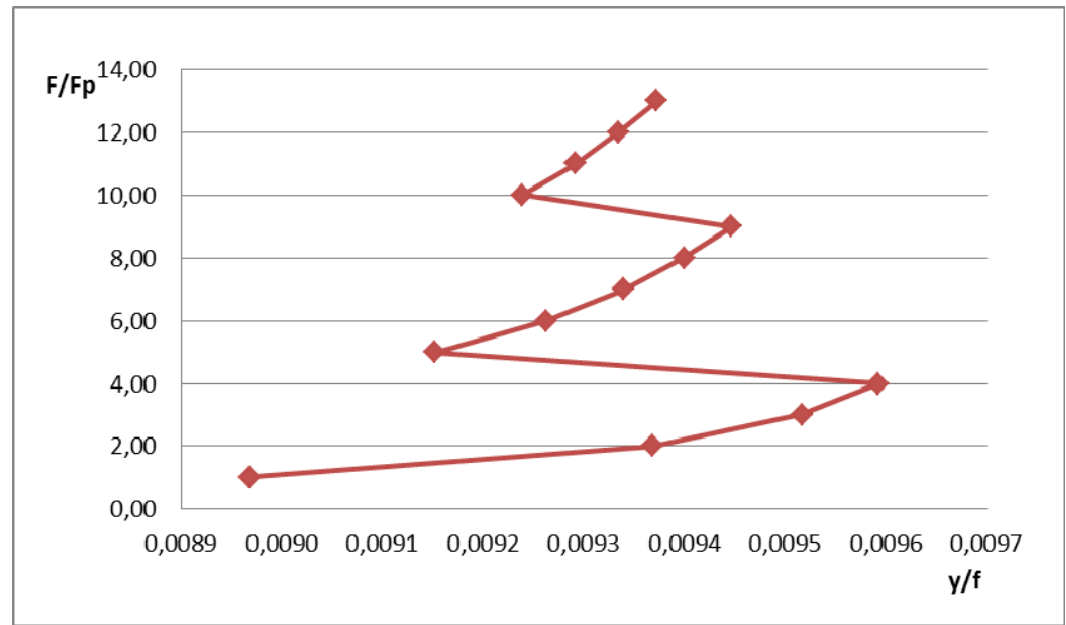

Figure 14. Mechanical testing; beam span of $140 \mathrm{~cm}, 11 \%$ of span

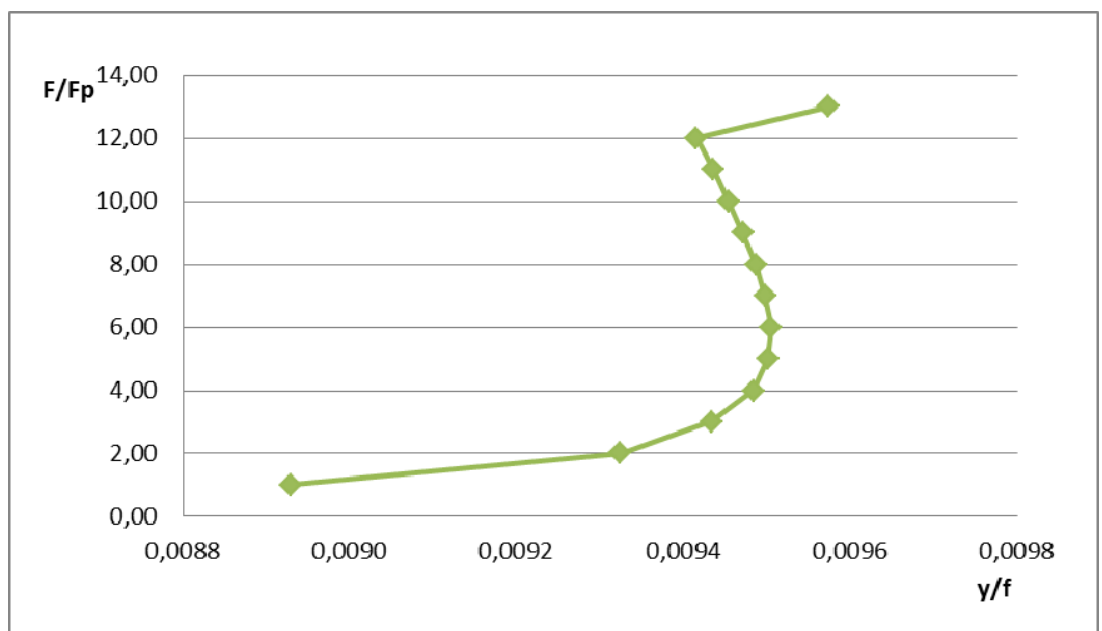

Figure 15. Mechanical testing; beam span of $140 \mathrm{~cm}, 17 \%$ of span 
Figures 16, 17, and 19 show corresponding diagrams for beams with spans of $240 \mathrm{~cm}$.

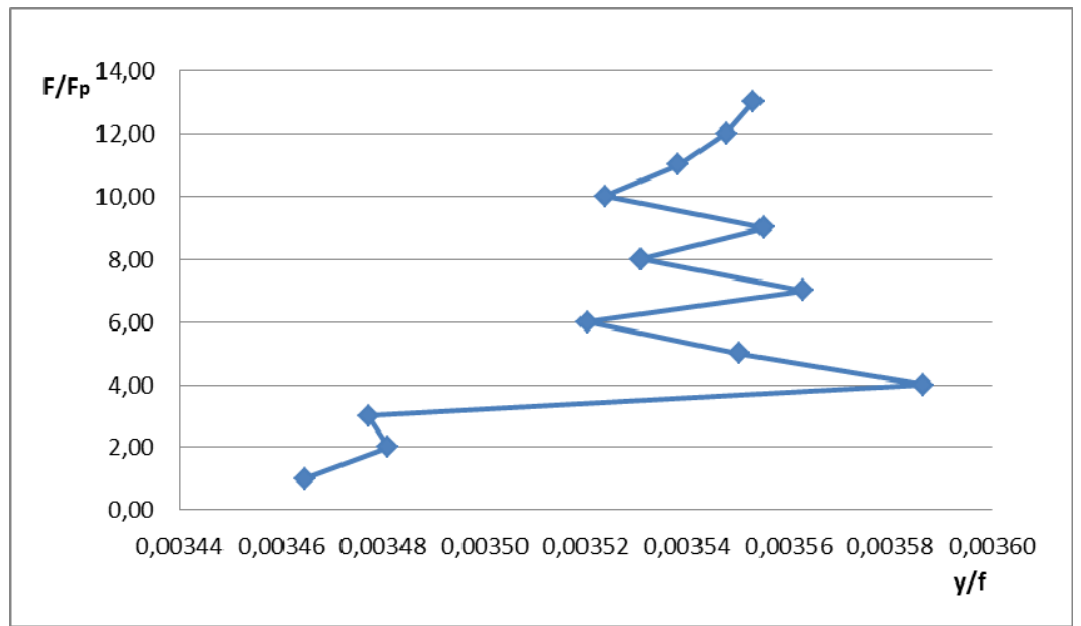

Figure 16. Mechanical testing; beam span of $240 \mathrm{~cm}, 6 \%$ of span

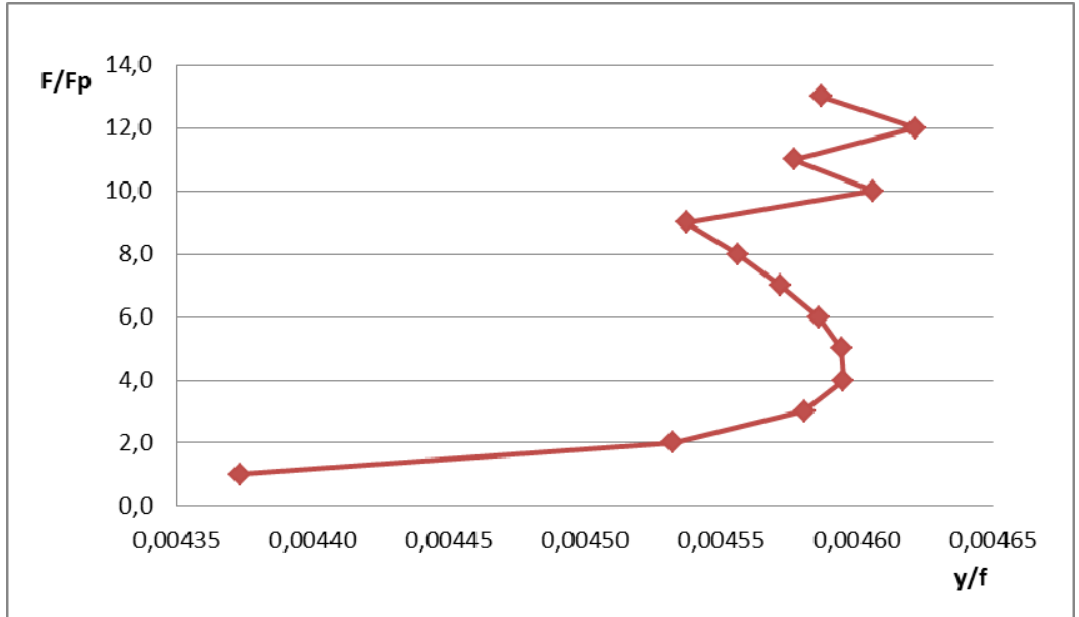

Figure 17. Mechanical testing; beam span of $240 \mathrm{~cm}, 11 \%$ of span

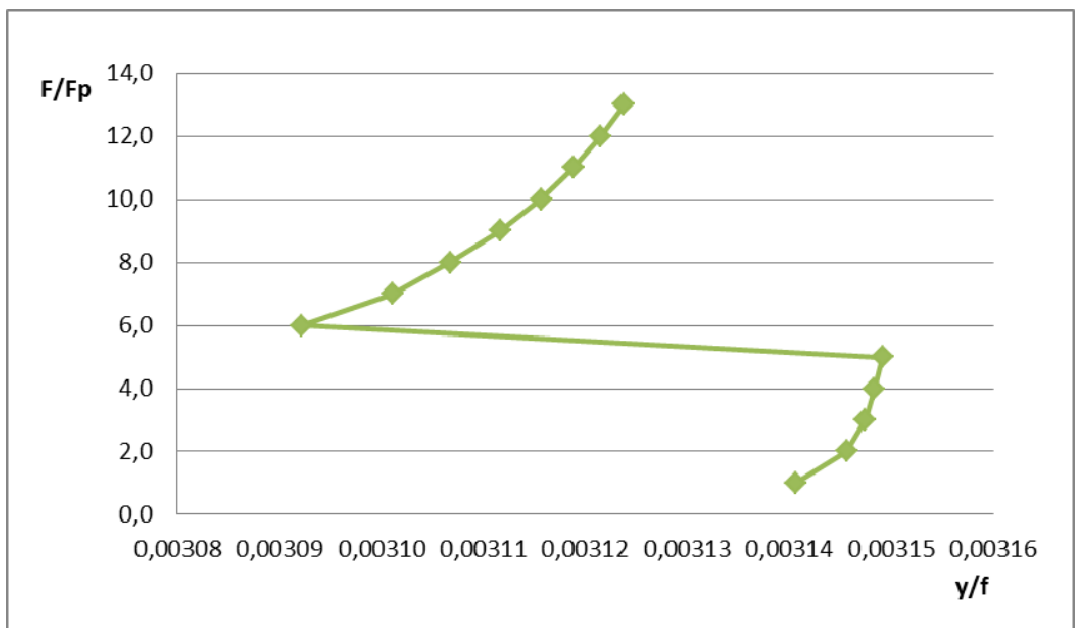

Figure 18. Mechanical testing; beam span of $240 \mathrm{~cm}, 17 \%$ of span 
Figure 19 shows results for all three distances between forces and supports for beam with $90 \mathrm{~cm}$ spans. Figure 20 shows results for all three beam spans for a $6 \%$ distance between forces and supports.

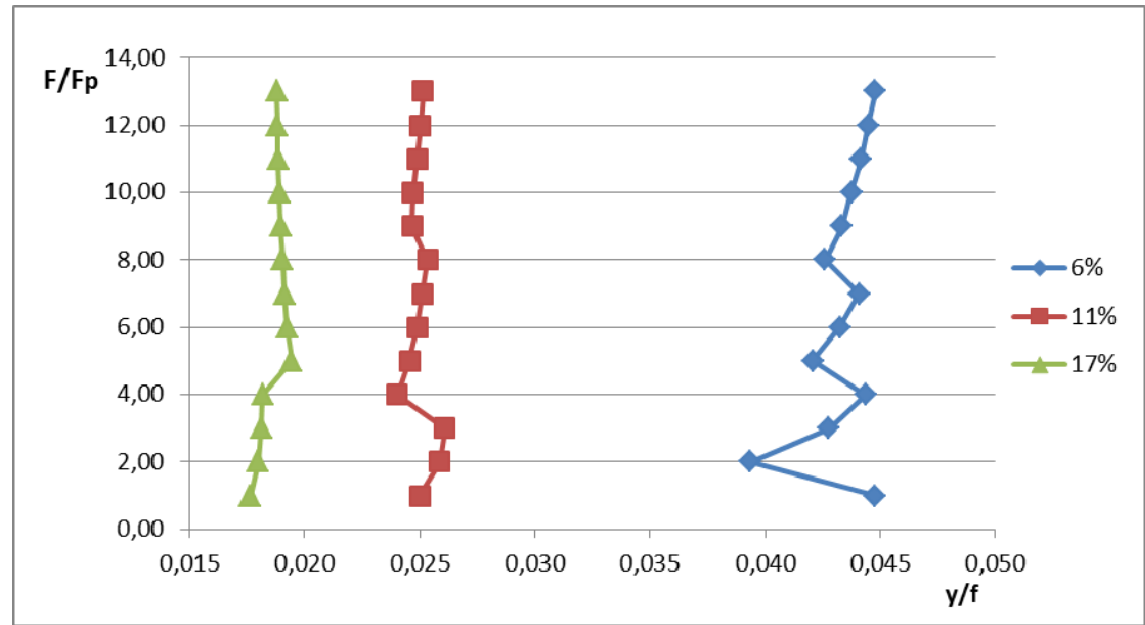

Figure 19. Mechanical testing; beam span of $90 \mathrm{~cm}$, all distances

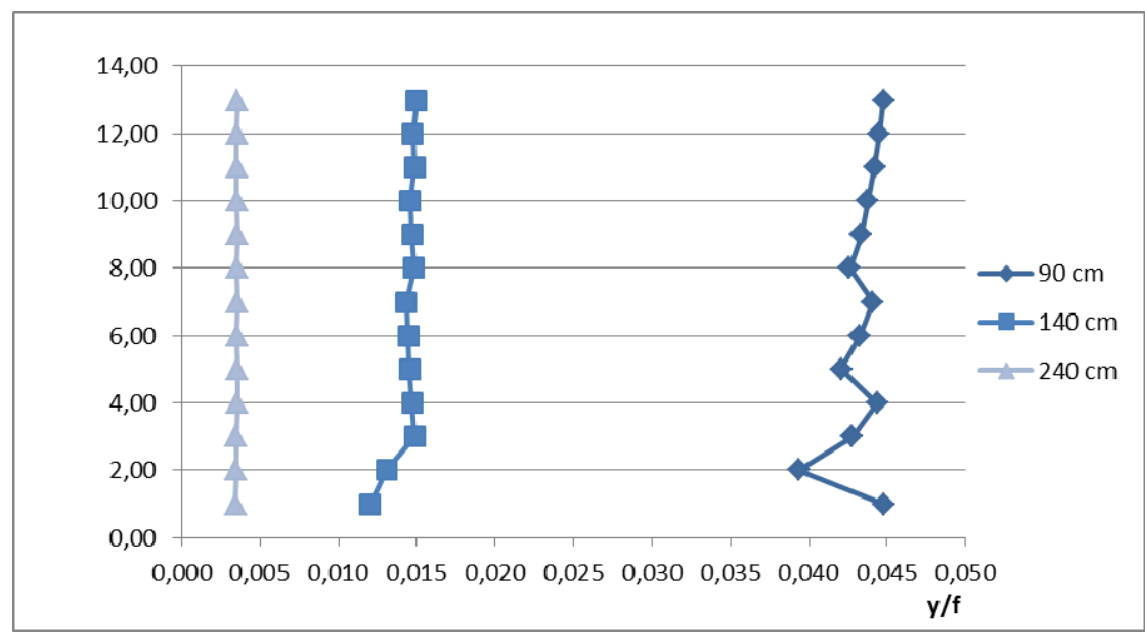

Figure 20. Mechanical testing; all beam spans, $6 \%$ of span

\section{Conclusion}

We analyzed the deformation of hollow, multi-layered, glass-fiber-reinforced polymer beams to show how they deformed during loading while being supported. Specifically, we showed how this deformation occurred near concentrated loads and near supports. We performed nonlinear analysis of three beams with different spans, varying the distance between the applied forces and supports, observing deformation near the supports.

From our calculations, we conclude the site of concentrated loading or stress is where the beam will fail. We also conclude that this failure is most commonly fast and brittle, but can be identified before failure occurs. Forces applied closer to the supports caused larger deformations, decreasing as they were moved away from the supports and closer to the mid-span. These results were presented in dimensionless diagrams, so they can be applied to similarly shaped and loaded beams to avoid unfavorable behavior in the presence of concentrated stress and load. 


\section{References}

[1] Šimunić, Ž. 2006: Polimeri u graditeljstvu, Sveučilište u Zagrebu, Građevinski fakultet, Zagreb (in Croatian)

[2] Štefić, T. 2013: Mogućnost primjene višeslojnih ploča od kompozitnih materijala kao nosivih konstrukcija u visokogradnji, Sveučilište u Splitu, Fakultet građevinarstva, arhitekture i geodezije, Split (in Croatian)

[3] Gerdeen, J.C.; Lord, H.W.; Rorrer R.A.L. 2006: Engineering Design with Polymers and Composites, CRC Press, Boca Raton

[4] ASTM Standard D3039, Standard Test Method for Tensile Properties of Fiber-Resin Composites 2008: ASTM International, West Conshohocken, DOI: 10.1520/D3039_D3039M-08. Available on www.astm.org

[5] Barbero, E.J. 2008: Finite Element Analysis of Composite Materials, CRC Press, Boca Raton

[6] Autodesk Robot Structural Analysis Professional 2010, Version 23.0.0.3128, Autodesk, Inc. 